Check for updates

The BMJ

fgodlee@bmi.com Follow Fiona on Twitter @fgodlee

Cite this as: BMJ2021;373:n1210 http://dx.doi.org/10.1136/bmj.n1210 Published: 13 May 2021

\title{
Covid-19: Why we must temper urgency with diligence
}

\section{Fiona Godlee editor in chief}

How should we balance the need for speed with our duty towards care and rigour? In the first days of the pandemic doctors who were faced with patients sick and dying from an unknown disease turned by necessity to existing drugs, those known to work against viral illness or to be potentially beneficial in multiorgan inflammatory disease. The list of these "repurposed" drugs is long, many with honourable records of safety and effectiveness in other conditions.

Almost all have fallen under scientific scrutiny. The Recovery trial, so impressively established in the very first days of the pandemic, ${ }^{1}$ has given us one remarkable positive finding: that a cheap and widely available drug, dexamethasone, reduces mortality in critically ill patients. ${ }^{2}$ Apart from this, and some emerging evidence of benefit from monoclonal antibodies, trials have almost all given existing drugs the thumbs down. 34

In response to the science, most countries have seen these drugs falling out of use for covid-19. ${ }^{5}$ But not so in India. As the country suffers a terrible second wave, ${ }^{6-8}$ patients with mild covid are receiving a "cocktail of multiple ineffective drugs and unneeded investigations" at great cost and unnecessary harm, say Akshay Baheti and colleagues, while those with moderate or severe covid struggle to procure indicated drugs and oxygen, even on the black market. ${ }^{9}$

Further trials are under way, ${ }^{4}$ including the relaunched Solidarity trial, focusing on the immune response.${ }^{10}$ And there is hope that the UK's recently announced antiviral task force will fill the gap in preventive treatments. ${ }^{11}$ But improved survival from covid has never been about drug treatments alone. Equally important are non-medical interventions: supportive and nursing care, and delaying ventilation. ${ }^{3}$ Nor should we forget the need for physical and mental rehabilitation for people who survive $^{12}$ and for long term and substantial investment in primary care. ${ }^{1314}$

The pandemic has brought other tools into sharp relief: quality improvement ${ }^{15}$ and clinical guidelines. The paradox, say Dipender Gill and colleagues, is that the imperative for guidance is greatest when evidence is scarce. ${ }^{16}$ Could our guideline producers be bolder in the face of uncertainty? Will the plans of the UK National Institute for Health and Care Excellence for dynamic, modular, and living guidance be the answer? ${ }^{17}$

We travel in hope that our leaders will continue to invest in open and high quality science and that good regulation and clear guidance will enable clinicians and patients to follow it. In this and future pandemics we must temper urgency with diligence.
Wise J, Coombes R. Covid-19: The inside story of the RECOVERY trial. $B M$ 2020;370:m2670. doi: 10.1136/bmj.m2670 pmid: 32641290

2 Rochwerg B, Siemieniuk RA, Agoritsas T, etal. A living WHO guideline on drugs for covid-19. BM/2020;370:m3379. doi: 10.1136/bmj.m3379 pmid: 32887691

3 Lee CK, Linder JA, Gates KL. Management of severe covid-19: progress and promise. BM/2021;373:n1147. doi: 10.1136/bmj.n1147 pmid: 33962966

4 Baraniuk C. Where are we with drug treatments for covid-19?BMJ 2021:373:n1109. doi: 10.1136/bmi.n1109 pmid: 33962913

5 Prats-Uribe A, Sena AG, Lai LYH, etal. Use of repurposed and adjuvant drugs in hospital patients with covid-19: multinational network cohort study. BMJ 2021;373:n1038doi: 10.1136/bmj.n1038

6 Thiagarajan K. Why is India having a covid-19 surge?BMJ2021;373:n1124. doi: 10.1136/bmj.n1124 pmid: 33931413

7 Narayan KMV. India's covid-19 catastrophe is a failure of national and globa public health and policy response to the pandemic. BMJ Opinion. 8 May 2021. https://blogs.bmi.com/bmi/2021/05/08/indias-covid-19-catastropheis-a-failure-of-national-and-global-public-health-and-policy-response-tothe-pandemic.

$8 \quad$ Nundy S. Covid-19 in India: Oxygen supplies run low, hospital fees run high BMJ Opinion. 7 May 2021. https:/blogs.bmi.com/bmi/2021/05/07/covid19-in-india-oxygen-supplies-run-low-hospital-fees-run-high.

9 Baheti AD, Gilada TI, Nagral S. The second covid-19 wave and the paradox of Indian healthcare. BMJ Opinion. 10 May 2021

https://blogs.bmj.com/bmj/2021/05/10/the-second-covid-19-wave-andthe-paradox-of-indian-healthcare.

10 Ledford H. International COVID-19 trial to restart with focus on immune responses. Nature 2021;7. doi: 10.1038/d41586-021-01090-z. pmid: 33963326

11 Mahase E. Covid-19: UK launches antivirals taskforce to deliver home treatments by autumn. BM/2021;373:n1077. doi: 10.1136/bmj.n1077 pmid: 33903129

12 White C. Surviving critical illness is only the beginning: why patients must be supported in the aftermath. BMJ Opinion. 22 Apr 2021. https://blogs.bmj.com/bmj/2021/04/22/surviving-critical-illness-is-only-thebeginning-why-patients-must-be-supported-in-the-aftermath.

13 Salisbury H. Helen Salisbury: General practice on the brink. BMI 2021;373:n1187doi: 10.1136/bmj.n1187 .

14 lacobucci G. Covid-19: “Exhausted” GPs need more support for future crises, says leader. BMJ2021;373:n1206doi: 10.1136/bmj.n1206

15 Shah A, Pereira P, Tuma P. Quality improvement at times of crisis. BMJ 2021;373:n928doi: 10.1136/bmi.n928

16 Gill D, Baker EH, Hitchings AW. We need clinical guidelines fit for a pandemic. BM/2021;373:n1093. doi: 10.1136/bmj.n1093 pmid: 33926903

17 National Institute for Health and Care Excellence. NICE strategy 2021 to 2026: dynamic, collaborative, excellent. Apr 2021. https://www.nice.org.uk/about/who-we-are/corporate-publications/thenice-strategy-2021-to-2026

This article is made freely available for use in accordance with BMJ's website terms and conditions for the duration of the covid-19 pandemic or until otherwise determined by BMJ. You may use, download and print the article for any lawful, non-commercial purpose (including text and data mining) provided that all copyright notices and trade marks are retained. 